\title{
Lessons from insect conservation in Russia
}

\author{
Sergey M. Govorushko ${ }^{1,2} \cdot$ Piotr Nowicki $i^{3}$ (1)
}

Received: 9 December 2017 / Accepted: 1 February 2019 / Published online: 7 February 2019

(c) The Author(s) 2019

\begin{abstract}
Insect conservation in Russia has a long history, but it has been developing partly independently from the conservation tradition of the Western world, and consequently it is characterised by certain peculiarities. While this means that in many aspects the Russian conservation system is lagging behind the accomplishments of other countries, some of its solutions could possibly serve as good examples to be followed elsewhere. We summarise the main features of the Russian conservationoriented activities and regulations to protect insect fauna, focusing on both their achievements and failures. In particular, we consider entomological microreserves, which represent a unique type of protected areas made of small fragments of land totally excluded from human economic activity, and devoted to the conservation (often active one) of specific insect groups. We also discuss the drawbacks of the expert assessment approach to select insects for the inclusion in the national and regional Red Data Books, which in Russian legal system entails protected status of the species. Finally, we outline the rationale of sozological analysis [the analysis of conservation value], which offers a useful alternative, allowing much more objective selection of insect species of conservation concern, based on numerous basic criteria reflecting both the status of the focal species and their societal values.
\end{abstract}

Keywords Entomological reserves $\cdot$ Legal protection $\cdot$ Red Data Books $\cdot$ Sozological analysis $\cdot$ Species prioritisation

\section{Introduction}

Due to its large territory and the pristine state of many of its ecosystems, the Russian Federation is bound to play an important role in the preservation of numerous Palearctic species, including insects (Tuzov et al. 1997; Griffin 1999; Lockwood and Sergeev 2000). Nevertheless, the status of insect communities in Russia is not free from threats and many species require dedicated conservation measures. Insect conservation in Russia has a long history, but at the same time its development, especially in recent years, has

Electronic supplementary material The online version of this article (https://doi.org/10.1007/s10841-019-00136-y) contains supplementary material, which is available to authorized users.

Piotr Nowicki

piotr.nowicki@uj.edu.pl

1 Pacific Geographical Institute, 7 Radio St., Vladivostok 690041, Russia

2 Far Eastern Federal University, 8 Sukhanova St., Vladivostok 690950, Russia

3 Institute of Environmental Sciences, Jagiellonian University, Gronostajowa 7, 30-387 Kraków, Poland been somewhat independent from the world-wide trends in species and habitat conservation. Consequently, while the present Russian conservation-oriented activities and regulations share certain common features with those applied in the European Union member states, the United States or Canada, they are also characterized by many peculiarities. The fact that the Russian conservation system is built partially disregarding the earlier successful examples of insect conservation in the Western countries (cf. Collins and Thomas 1991; New et al. 1995; Thomas et al. 2011) may be considered a drawback, but on the other hand there is no reason to ignore the Russian own experiences in this respect. The aim of the present paper is thus to provide a summary of the past and present status of insect conservation science in Russia, as well as to outline its main characteristics. We believe that the Russian achievements and failures could serve as lessons to the outside world, respectively as good examples to follow and as mistakes to avoid while setting conservation programmes. 


\section{Historical overview}

The beginnings of insect conservation in Russia date back to the medieval times, when the laws for the protection of wild honey bees were established. For several centuries bee products such as honey (used as traditional drink or the replacement of sugar and medicines) and wax (utilised in the production of church candles among others) served as important articles of both domestic and foreign trade as well as currency to pay tributes and taxes (Klyuchnikov 2005; Sviridov 2011). Therefore it is not surprising that the "Russkaya Pravda [Russian Truth]", one of the first collections of laws (1113 AC), included five articles devoted to the protection of the rights of wild-honey collectors. They enforced penalties not only for stealing bees, honey, honeycombs, but also for damaging trees with wild hives; moreover, during gathering honey the collector was supposed to leave about half of the comb to the bees (Pereletov 2008). While all the above regulations were designed as measures for protecting businesses, they obviously benefited wild honey bees as well.

The modern conservation era started with the Forest Charter passed in 1888, which defined the concept of protective forests with special regime of unconditional preservation of several types of forests, including those safeguarding coast or agricultural fields as well as mountain and suburban forests (Chernov 2002). Shortly afterwards came the idea of nature reserves as the fragments of lands withdrawn from any economic use, where all the elements of nature are legally protected (Moskalenko 2016). Interestingly, the first such nature reserve, "Chapli" created in 1898 near the village of Askania Nova (currently Eastern Ukraine), encompassed 545 hectares of virgin steppes, which represent one of Europe's insect biodiversity hotspots (Tye 1991). Nevertheless, no insect species were mentioned explicitly in the legislative statutes of this or later reserves (Sviridov 2011). It was only in the 1920s that the need for the dedicated actions to protect insects (bees, butterflies, beetles), especially in urbanised areas, was clearly formulated (Kozhevnikov 1926).

\section{Entomological microreserves}

The twentieth century development of entomology in Russia brought more understanding of the role played by insects in ecosystems and of the ecosystem services provided by them. The growing appreciation of insect importance as pollinators, food resource for various animals, or natural enemies of agricultural pests led to the idea of entomological microreserves, which would serve as refuge areas for insects (Grebennikov 1972, 1990). Their establishment became to be perceived as urgency especially in agricultural regions, where the agriculture intensification and the resulting increase in the application of chemical fertilisers as well as herbicides and insecticides seriously impacted insect communities, decimating not only the targeted pest insects but also many beneficial ones (cf. Tilman et al. 2002; Beketov et al. 2013).

In particular, the mass deaths of bumblebees was highly publicised, and it caused legitimate concerns about the fate of these important pollinators (Byvaltsev 2009a). Consequently, in 1972 the decision of the Omsk regional Executive Committee established, the country's first entomological reserve "Shmelinnye Kholmy [Bumblebee Hills]", encompassing 6.5 hectares of forest-steppe in the Isilkulsky district, intended primarily for the protection of this group (Kassal et al. 2016). A year later the second bumblebeeoriented microreserve was created near the settlement of Ramon (Voronezh oblast). Similar microreserves soon followed in the Novosibirsk and Irkutsk oblasts, the Stavropol Krai, and the Chuvash Autonomous Republic. It is worth noting that all these microreserves should not be perceived merely as the fragments of land set aside for bumblebees, but instead they represent areas of active conservation, where artificial holes, simulating the burrows of rodents, are made in the ground to serve as nesting sites for bumblebees (but also for some other insects), improving their breeding success and thus increasing local abundances (Chenikalova et al. 2008).

The success of the aforementioned bumblebee sanctuaries provided inspiration for establishing further microreserves intended for other insect groups, such as butterflies or orthopterans. The best example of them is the network of three microreserves set up in the neighbourhood of Pushkino (Moscow oblast), spanning a wide range of meadow, steppe and deciduous forest habitats (Kochetova et al. 1986). Furthermore, in the forest zone of Russia about 80 myrmecological microreserves were established (Zakharov 2003). They are mostly designed for the conservation of the red wood ants of the genus Formica. Many of them reach considerable sizes and can in fact be classified as standard nature reserves. This category includes the myrmecological reserves of the Upper Klyazma (600 ha; Solnechnogorsky district, Moscow oblast) or Gusevsky Forest (111 ha; Gus-Khrustalny district, Vladimir oblast) to name just a few. In general, however, as the name implies the entomological microreserves are relatively small in size. Although they are mostly established as a result of local initiatives (see below), and hence no comprehensive information exists about their numbers and areas across Russia, the data we managed to gather suggest that they are usually below 40 ha (Fig. 1).

The Russian entomological microreserves may superficially resemble small-scale nature reserves existing in other 


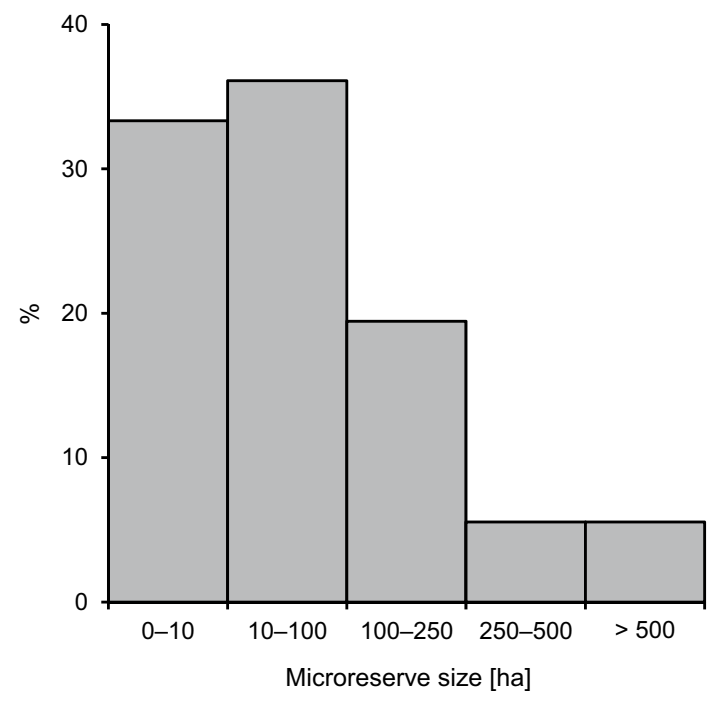

Fig. 1 Size distribution of entomological microreserves in Russia, based on a sample of 36 microreserves with detailed information available (minimum: 0.05 ha; median: 39.4 ha; maximum: 3581 ha). It should be noted that the presented distribution is strongly positively biased, because there is a huge number of apparently small microreserves, for which the size is not reported

parts of the world (Chape et al. 2008), and in particular the network of Natura 2000 sites (Gaston et al. 2008; Evans 2012), established in the European Union as one of the practical implementation steps of its Habitats Directive (European Commission 1992). Many Natura 2000 sites aimed at the preservation of insect species listed in Annexes of the Habitats Directive are indeed similarly small in size, reaching a few tens to a few hundreds hectares (European Environment Agency 2018). Nevertheless, the main difference is that the Russian entomological microreserves, unlike Natura 2000 sites, do not form a harmonised system, but rather an assemblage of small protected areas functioning completely independently from one another. They have mostly been created as a result of uncoordinated bottomup initiatives of local authorities, state forest directorates or even schools or nature enthusiast organisations (Grebennikov 1990; Logvinovsky 1996; Chenikalova et al. 2008). A consequence of such a situation is that hardly any attention is given to spatial configuration of microreserves that could ensure their sufficient connectivity and hence allow the exchange of insect individuals (and their genes) among the microreserves. This does not necessarily imply a strong isolation of microreserves, as they are often located within large and well-connected expanses of natural or semi-natural habitats. Nevertheless, the existing network of microreserves may prove not robust enough in the case of increasing habitat fragmentation in future.

Regretfully, due to the complete lack of insect monitoring or even systematic entomological surveys in Russia, the effectiveness of microreserves in preserving insect communities and/or viable populations of target species cannot be reliably evaluated empirically. Nevertheless, based on theoretical grounds the system of microreserves offers a highly promising solution for insect conservation. Small area of a single microreserve significantly simplifies the withdrawal of land from any economic activity. Microreserves can also be easily created in lands, which are hardly accessible due to topography (ravines, steep slopes, etc.) and have thus low economic importance, but potentially high natural values. Besides, networks of small, but close-lying sites, may be optimal for the regional persistence of insect species, many of which are known to form typical metapopulations (Thomas and Hanski 1997). As postulated in the SLOSS debate (Gilpin and Diamond 1980) microreserve networks should also be more resistant to catastrophic events and disease spreading than a single large protected area (Soule and Simberloff 1986; Shafer 2001). Specifically in the case of insects, which typically have small area requirements and narrow but diverse habitat requirements, such networks are likely to support much larger numbers of species (Baz and Garcia-Boyero 1996), especially those that prefer transition habitats or habitat egdes (Fletcher et al. 2007; Nowicki et al. 2013).

On the other hand, in the light of SLOSS debate smallscale protected areas such as microreserves have inevitable drawbacks as well. First of all, they are subject to strong impacts from the surrounding countryside (Soule and Simberloff 1986; Primack 2002), which especially within agricultural landscapes are predominantly negative (e.g. pesticides, fertilisers). In addition, microreserves are prone to succession, which constitutes a major threat to precious insect communities, often associated with early successional stages of semi-natural habitats (Fenner and Palmer 1998; Bubova et al. 2015). Over a large area the succession does not take place strictly simultaneously, so the whole set of insect species is preserved thanks to the existing heterogeneity in successional stages; in turn, small sites rarely provide such an effect. Finally, environmental stochasticity, e.g. adverse weather conditions (drought, abnormally cold winter, etc.) or habitat disturbances (floods, fires) in a particular year, can make the entire microreserve temporarily unsuitable for certain species and lead to their local extinctions, even if its state of environment is favourable in the long term perspective. Nevertheless, the role of environmental stochasticity as a factor shaping insect populations should not be overestimated, since its importance in this respect has recently been questioned (León-Cortés et al. 2003; Nowicki et al. 2009, 2015; Kajzer-Bonk et al. 2013).

More generally, the microreserves share the disadvantages of any area-based passive conservation strategies. It is commonly known that the protected status of the territory does not guarantee the preservation of specialist species with 
particular requirements, and there were several cases when previously quite common species completely vanished from the Russian microreserves. A good example in this respect is the Apollo butterfly Parnassius apollo, which went extinct in the Prioksko-Terrasny reserve (Kochetova et al. 1986). Its caterpillars have a narrow trophic niche (Nakonieczny et al. 2007), and the imminent reason for the species disappearance was ploughing of the field adjacent to the reserve, which constituted the local reservoir of the Sedum album host plants (ZooClub 2017). Similar cases of the Apollo butterfly suffering from habitat loss within protected areas are in fact well known also from the Western Europe (Munguira 1995; Nakonieczny et al. 2007).

\section{Other protected areas and their role in insect conservation}

There are five 'federal' categories of protected areas in the Russian Federation: state nature reserves (zapovedniks; $n=103)$; national parks $(n=48)$; natural parks $(n=64)$; (4) state nature-sanctuaries $(n=64)$; and natural landmarks ( $n=8360$, including both federal and regional natural landmarks). Apart from natural landmarks, which roughly correspond in size with microreserves, the remaining categories can be classified as large-scale protected areas as typically exceeding a thousand square kilometres. In addition, the current nature conservation legislation allows the designation of further protected areas of regional and local importance, and although so far such areas have been established in only about one-third of the regions, they constitute an overwhelming majority ( $87 \%$ ) of the Russian protected areas (Danilova et al. 2018).
Altogether, protected areas cover $11.4 \%$ per cent of the land surface of the country (Stepanitskiy 2016). Obviously, the fact that such a substantial portion of land is mostly withdrawn from economic use and devoted to the preservation of nature is highly positive for biodiversity conservation in general. Nevertheless, other than the entomological microreserves described in the previous section, the protected areas bring relatively little specific contribution to the insect conservation in Russia. It is so for several reasons.

First of all, while in theory the designation of a protected area should follow a comprehensive surveys of all the biotic and abiotic elements present within its prospective territory (Stepanitskiy and Sinitsyn 2008), in practice the decisions are typically taken on the basis of the occurrence of a few charismatic species, mostly large mammals or birds, and the generally favourable status of habitats. The information on the situation of insects of conservation concern is often disregarded in the process. It is symptomatic that among 47 state nature reserves existing in the European part of Russia only 33 (70\%) officially report to include insect species listed in the Russian Red Data Book (Speranskaya and Zaitsev 2011). Moreover, in most cases no more than 1-2 species are reported and quite often they are restricted to relatively wide-spread Apollo butterfly species, namely $P$. apollo and $P$. mnemosyne (Fig. 2). While a similar quantitative assessment is not possible for the Asian state nature reserves due to the lack of comprehensive data, this fact itself indicates that the officially reported situation is even worse in this part of Russia. Obviously, this does not mean that many insect species of conservation concern are totally absent from the Russian state nature reserves since they may simply go undetected (MacKenzie et al. 2002; Kery and Schmid 2004), but rather that their status there is neglected, which is still a negative sign.
Fig. 2 The reported occurrence of Red Data Book insect species in 47 state nature reserves of the European part of Russia

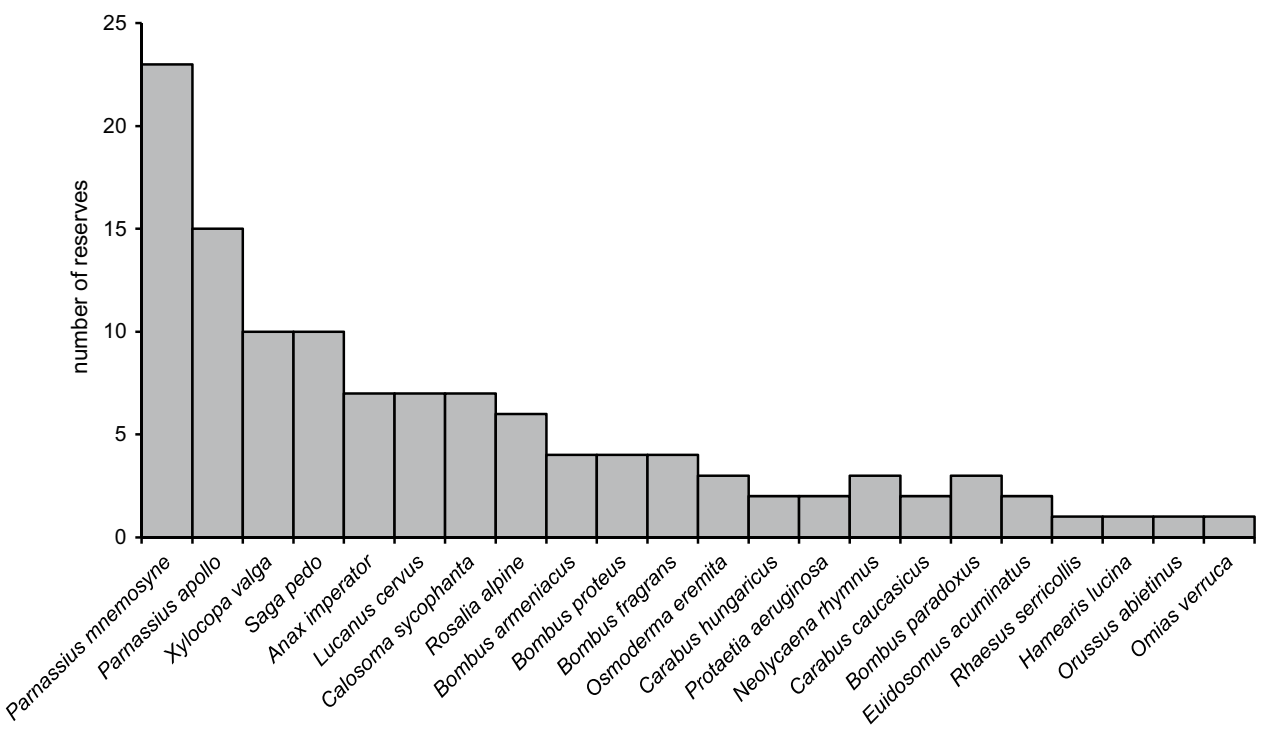


Another disadvantage of Russian protected areas in respect to insect conservation is their predominant focus on the passive preservation of the current (assumingly favourable) state of their ecosystems, achieved primarily through prohibiting or restricting various forms of human activity, whereas many insects would often benefit from active management of their habitats (Fenner and Palmer 1998; Thomas et al. 2011; Bubova et al. 2015). Apart from this, there is a clear imbalance between the habitat composition of protected areas and the habitats required by endangered insect species. For instance, in most regional Red Data Books insects are dominated by grassland species, but nature reserves are predominantly covered with forests and wetlands, whereas grassland habitats typically account for only a few percent of the overall protected area (Lagunov 2004; Platonova and Belova 2011).

The geographical coverage of the protected areas is also not adequately representative for the country. For instance, three insect biodiversity hotspots were identified in Russia: Caucasus, Altai-Sayan mountains, and the southern part of Primorsky Krai (Shchurov and Zamotajlov 2006; Barkalov 2007; Lelej and Storozhenko 2010), but within these regions there are hardly any protected areas in which insects are declared as the objects of conservation (Fig. 3). Similarly, there is no particular focus on faunistic studies of insects or their monitoring in the hotspot regions. All this implies that biogeographic knowledge is not really utilised in insect conservation in Russia.

\section{Compiling Red Data Books}

Independently of the protected area-based conservation, there have been efforts to identify insect species that deserve individual protection in Russia. Already in the 1960s it was postulated that their selection should be based on objective criteria, reflecting the species vulnerability, such as extinction risk, rarity, or biogeographical relict status (Kurentsov 1964). A decade later such criteria were first formulated by Ermolenko (1973) and after slight modifications they were subsequently agreed on at the national entomological meeting (Mirzoyan 1975). According to them, the protected species should include "(i) all the useful, rare, relict and endemic insects; (ii) insects with aesthetic values; and (iii) intact communities of insects in natural biocoenoses, except of those explicitly harmful". Such an approach represented a noticeable step away from protecting only the insects of importance for human economy, which previously used to be the case.

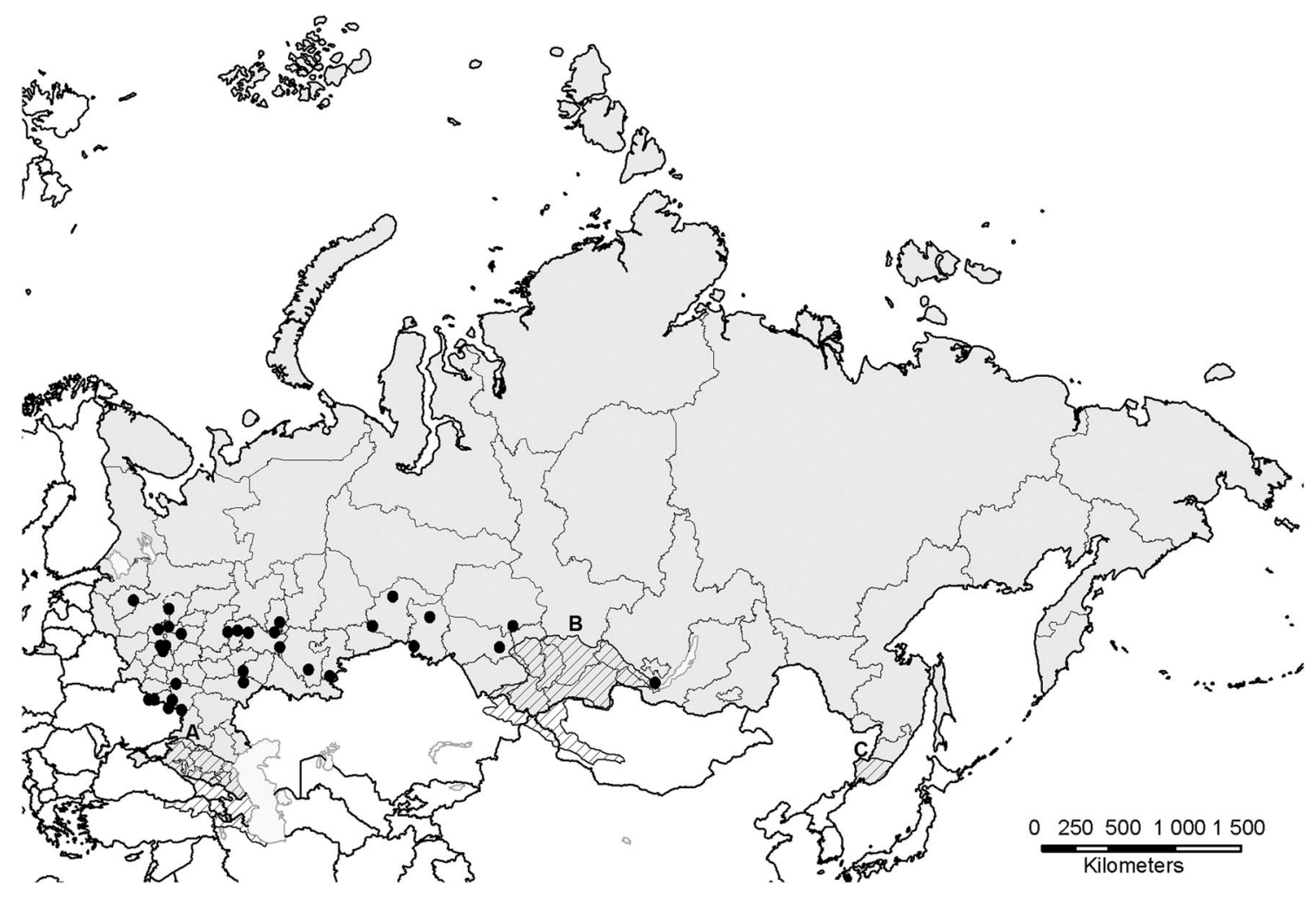

Fig. 3 The distribution of protected areas where insects constitute the main objects of conservation (black dots) in relation to the location of three biodiversity hotspots in Russia (hatched fragments: A = Caucasus; B = Altai-Sayan mountains, $\mathrm{C}=$ southern part of Primorsky Krai) 
The first Red Data Book of the former Soviet Union (USSR), which appeared in 1978, contained no insects at all, and only its second edition of 1984 listed 202 insect species (Borodin et al. 1984; Nikitsky and Sviridov 1987). In turn, the Red Data Book of the Russian Soviet Republic (RSFSR) published in parallel in 1983 included 34 insect species (Eliseev 1983). Obviously, the insect fauna of RSFSR may be expected to be slightly less diverse than that of the USSR, since the former territory was about three quarters of the latter $\left(17,125,200\right.$ vs. $\left.22,402,200 \mathrm{~km}^{2}\right)$, excluding the insectrich southern regions of Central Asia, Transcaucasia, and Eastern Europe. Nevertheless, the difference should presumably be slight only, and in fact a vast majority of the insect species listed in the USSR Red Data Book occur in Russia as well. Instead, the striking discrepancy in the representation of insects in the two aforementioned Red Data Books can be mostly explained by the different methodologies adopted for species selection in both cases (Sviridov 2011). The approach used for the Russian Red Data Book was evidently more stringent and thus restrictive ('conservative'), being based on only two criteria for species inclusion, namely (i) a species being at the verge of extinction; or (ii) a species experiencing a continuous decline. With the lack of the data on species abundances, the evaluation of the latter criterion was primarily based on the reduction of distribution ranges. Nevertheless, the criterion was still highly exclusive, because the relevant information was hardly available for most insect species. The objective assessment of the extinction risk was even more problematic and hence it was arbitrarily decided that the condition of being at the verge of extinction is met only by species with at most five local populations remaining (Sviridov 2011). In contrast, the selection of species for the Soviet Union Red Data Book relied also on additional criteria, such as endemism for the state, restricted distribution or aesthetic values, thus being definitely more lenient and inclusive (Borodin et al. 1984).

Almost immediately after their publication, both the Soviet Union and Russian Red Data Books met with criticism, mostly for following the approach of the first version of the IUCN Red Data Book (1966), which in the Western world was already considered obsolete and criticised for not being based on quantitative criteria (Shchurov and Zamotajlov 2006). Soon the works on the new editions began and the guiding principles were formulated as follows (Mazin 1999):

1. A species should be listed in the Red Data Book only if it requires urgent protection; its economic, scientific, aesthetic and other values should only be treated as a secondary criterion;

2. The need for the species protection must be confirmed by objective data on the status of its populations across different parts of the distribution range;
3. Species should be selected regardless of their taxonomic position, i.e. all insect groups should equally considered;

4. For the selection of species it is desirable to take into account the interactions between different species.

With the collapse of the Soviet Union in 1991, the preparation of its Red Data Book was no longer on the agenda, and publishing its Russian version was delayed considerably. The long-awaited book eventually came out in 2001, and until now it remains the most actual edition. It comprises 95 insects species, representing five taxa: Odonata-1 species; Orthoptera-2 species; Coleoptera-36 species, Hymenoptera-23 species; and Lepidoptera-33 species (DanilovDanilyan 2001; Tikhonov 2002). Although, the species selection has been based on much more objective criteria than in the case of the first Russian Red Data Book, it is still widely believed that listing the species does not always truly reflect their threatened conservation status. This is particularly true for some charismatic and/or wellstudied, yet relatively common Lepidoptera, such as the butterflies Neolycaena rhymnus or P. mnemosyne, and moth Actias artemis (Gorbunov and Murzin 2009; Poltavsky and Poltavskaya 2010). In turn, less popular species, for which even basic information on their distribution in Russia is hardly available (Fig. 4), are less likely to be included in the Red Data Book.

In general, certain taxa appear overrepresented in the Russian Red Data Book, while many others are likely to be somewhat overlooked. The former group comprises honey bees and bumblebees (Apis spp., Bombus spp.), stag beetles (Lucanidae), and swallowtail butterflies (Papilionidae), with nearly or over $10 \%$ of their species listed in Red Data Book, whereas the representation of other taxa is usually ca. $1 \%$ (Table 1). The over-inclusiveness of 'flagship' insect taxa, popular due to their charismatic appearance and/or important role in ecosystems, is obviously not only a Russian ailment, but rather a general problem of virtually all Red Data Books or Red Lists across the world (cf. Collins and Morris 1985; Henning et al. 2009; Nieto and Alexander 2010; van Swaay et al. 2010; Cardoso et al. 2011). The situation is well understandable, because in the case of popular species being subject to numerous studies it is simply easier to gather evidence that they meet the defined criteria. However, in the Russian reality such an over-inclusiveness of the Red Data Book is not merely an academic problem, because unlike the IUCN Red Data Book and most of their national editions or Red Lists, which are not legally binding documents, but only provide recommendations, in Russia listing a species automatically entails its nationwide legal protection. Moreover, the protected species status is granted regardless of the threat category, i.e. for all the species classified as Critically Endangered (CR), Endangered (EN) or Vulnerable (VU).

In practice, however, such a status brings hardly any active conservation of a species, and it is limited to a ban 


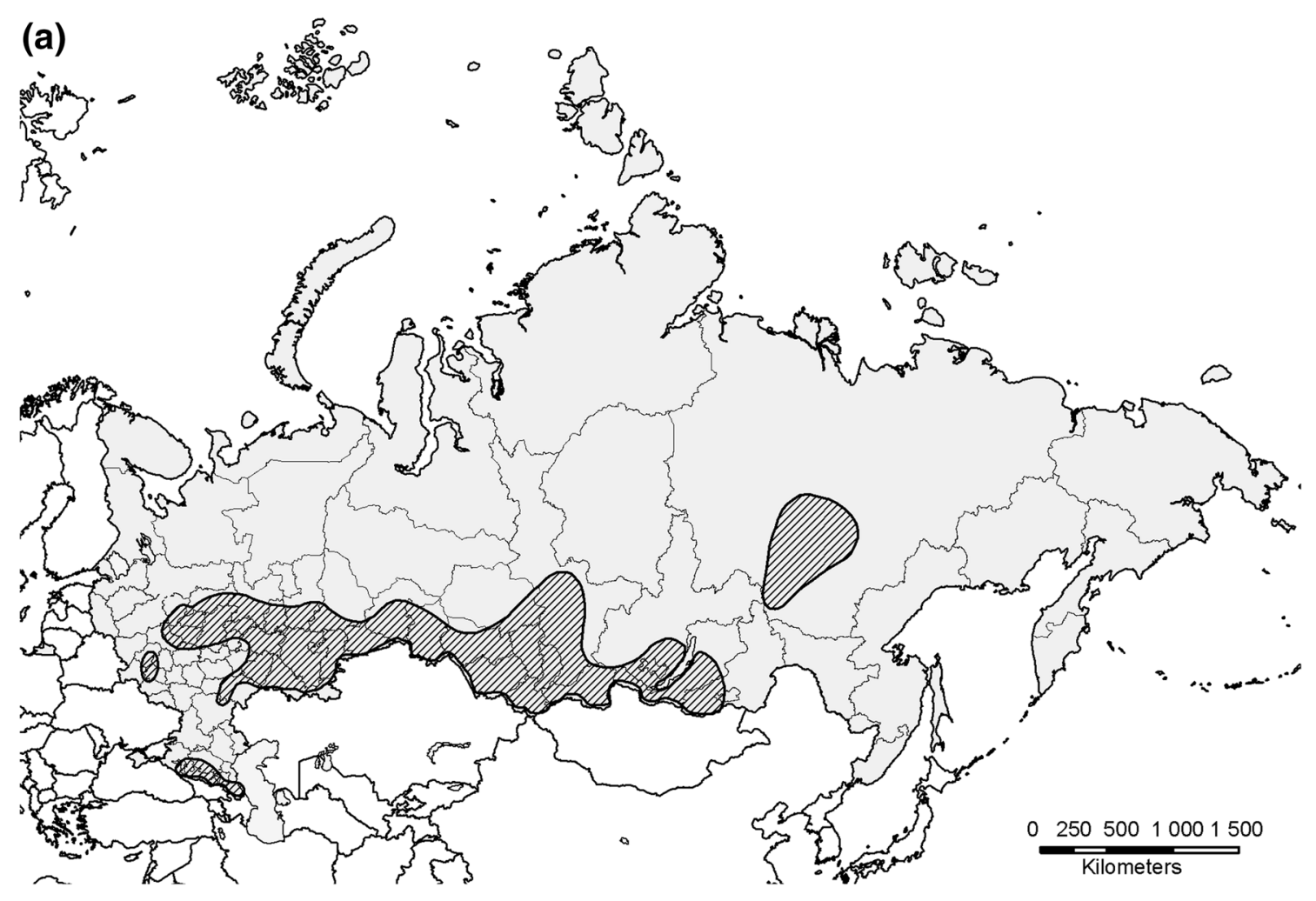

(b)

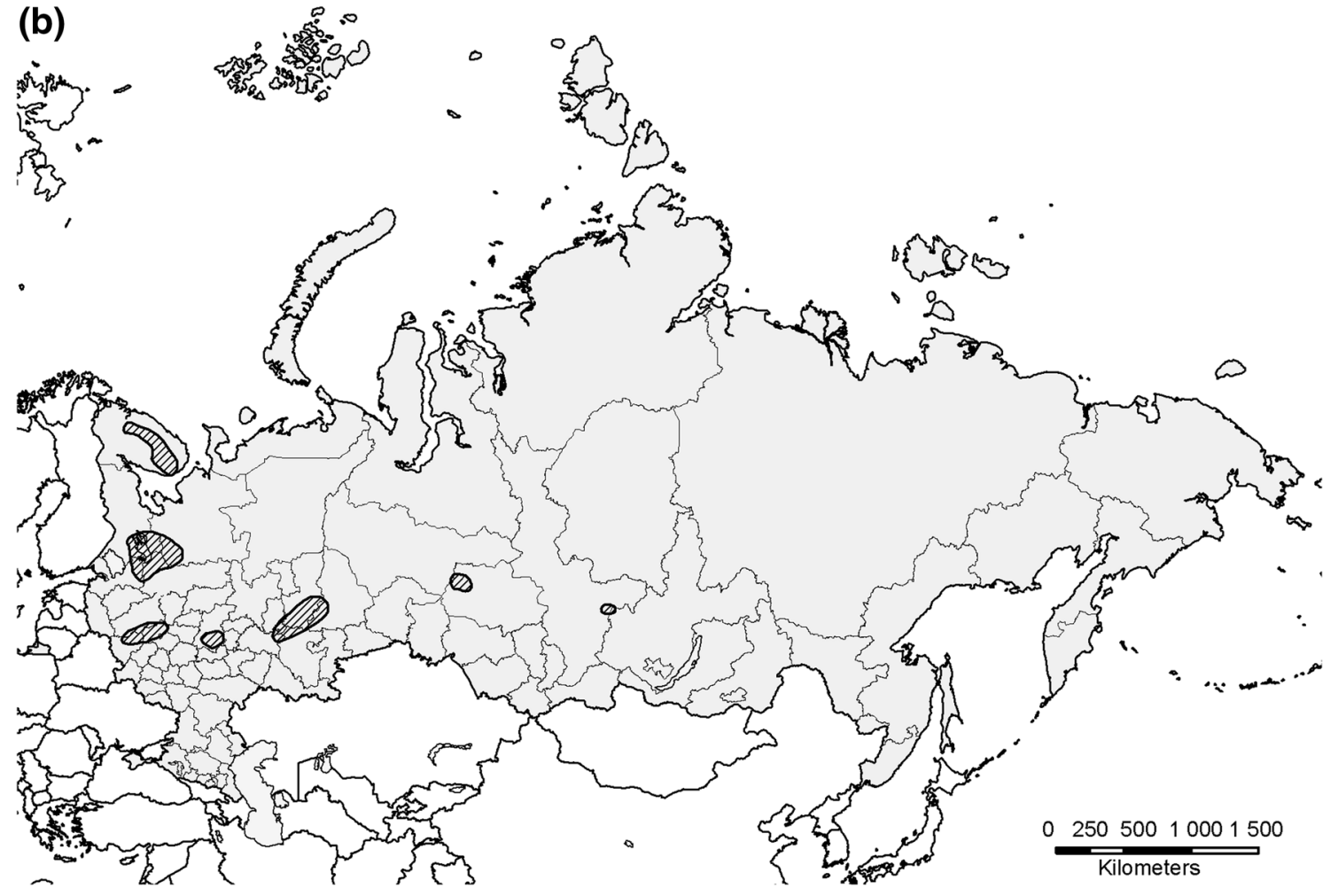

Fig. 4 The known distribution ranges (hatched areas) of selected insect species listed in the Russian Red Data Book: a the butterfly Parnassius apollo - an example of intensively studied species with well-known distribution; b the sawfly Acantholyda flaviceps-an example of species with only fragmentarily known distribution 
Table 1 Representation of insect groups in the Russian Red Data Book

\begin{tabular}{|c|c|c|c|c|}
\hline \multirow[t]{2}{*}{ Taxon } & \multicolumn{2}{|c|}{ Species richness in Russia } & \multicolumn{2}{|c|}{$\begin{array}{l}\text { Red Data Book } \\
\text { species }\end{array}$} \\
\hline & $N$ & Source & $n$ & $\%$ \\
\hline Dragonflies and damselflies (Odonata) & 154 & Haritonov and Eremina (2010) & 1 & 0.65 \\
\hline Hymenopterans (Hymenoptera) & & & 23 & \\
\hline Sawflies (Symphyta) & ca. 1100 & Sundukov and Lelej (2009) & 10 & 0.91 \\
\hline Bradynobaenid wasps (Bradynobaenidae) & & & 1 & \\
\hline Cuckoo wasps (Chrysididae) & & & 1 & \\
\hline Ants (Formicidae) & 264 & Belokobylsky and Lelej (2017) & 1 & 0.38 \\
\hline Digger bees (Anthophorini) & & & 1 & \\
\hline Honey bees (Apis spp.) & 2 & Engel et al. (2009) & 1 & 50 \\
\hline Bumblebees (Bombus spp.) & 90 & Byvaltsev (2009b) & 8 & 8.89 \\
\hline Butterflies and moths (Lepidoptera) & ca. 8900 & Sinev (2008) & 33 & 0.37 \\
\hline Skippers (Hesperiidae) & 55 & Klepikov (2002) & 1 & 1.82 \\
\hline Nymphalids (Nymphalinae) & 130 & Gordeev (2016) & 2 & 1.54 \\
\hline Satyrids (Satyrinae) & 198 & Tuzov et al. (1997) & 2 & 1.01 \\
\hline Swallowtails (Papilionidae) & 35 & Streltsov and Gluschenko (2005) & 5 & 14.29 \\
\hline Lycaenids (Lycaenidae) & & & 8 & \\
\hline Metalmarks (Riodinidae) & & & 1 & \\
\hline Hawk moths (Sphingidae) & & & 2 & \\
\hline Owlet moths (Noctuidae) & & & 6 & \\
\hline Silk moths (Bombycidae) & & & 1 & \\
\hline Tiger moths (Arctiidae) & & & 2 & \\
\hline Puss moths (Notodontidae) & & & 1 & \\
\hline Tussock moths (Lymantriinae) & & & 2 & \\
\hline Orthopterans (Orthoptera) & & & 2 & \\
\hline Beetles (Coleoptera) & & & 36 & \\
\hline Longhorn beetles (Cerambycidae) & 583 & Danilevsky (2014) & 9 & 1.54 \\
\hline Weevils (Curculionidae) & & & 5 & \\
\hline Ground beetles (Carabidae) & ca. 1950 & Belova (2014) and Koshkin et al. (2016) & 12 & 0.62 \\
\hline Scarab beetles (Scarabaeidae) & 435 & Kabakov (2006) & 6 & 1.38 \\
\hline Stag beetles (Lucanidae) & 20 & Zinchenko and Ivanov (2006) & 2 & 10 \\
\hline Leaf beetles (Chrysomelidae) & & & 1 & \\
\hline Click beetles (Elateridae) & & & 1 & \\
\hline
\end{tabular}

on killing or capturing its individuals, which for insects is tantamount with the ban on collecting its specimens. Occasionally, this may in fact have an adverse effect, since the declaration of legal protection of previously little known species increases public interest in them, which also attracts illegal collecting. On the other hand, collecting is rarely (if ever) responsible for insect species declines (cf. Thomas et al. 2011). Instead, it is the destruction or deterioration of their habitats, which almost always constitutes the most serious threat (Collins and Thomas 1991). Regretfully, the legal protection of a species is not associated with the protection of its habitats in Russia, as it is now required in the European Union member states according to the Habitats Directive. For the effective conservation of insect species in Russia it would be thus highly desirable to follow the example set by the Habitats Directive, and introduce legislative changes aimed at the preservation of insect habitats. Some of the solutions are fairly evident, e.g. prohibition of pesticide and fertiliser use at the edges of the cultivated areas and near hedge rows, or creation of uncultivated strips around large-scale agricultural fields to serve as refugia for natural enemies of pest species, whereas others may be quite specific, e.g. restriction on the use of antiparasitic drugs such as vermectins, which are toxic for dungfeeding invertebrates (Strong and Wall 1994; Conforti et al. 2018). Besides, many insect habitats may benefit from active management, such as mowing or grazing (see Bubova et al. 2015). Hence, certain economic activities may be compatible with insect conservation and they should not only be allowed, but also encouraged within protected areas. In turn, in agricultural lands it 
would be desirable to seed field margins with nectar-rich herbs such alfalfa, sainfoin or phacelia. These are known to provide vital resources for a wide range of pollinating insects, supporting their viable populations (Kovalenko 2009; Medvedsky and Medvedskaya 2010).

It has recently been postulated that assigning Red Data Book categories and thus legal protection to insect species in such vast and diverse country as Russia should optimally derive from the analyses of its regional Red Data Books (Poltavsky and Poltavskaya 2010). Nevertheless, at present this ambitious goal seems unachievable despite the wealth of regional publications. Out of 85 Russian regions, 75 have their own Red Data Books, and in many of them two or even three editions (e.g. in Karelia) have been published so far; while the early editions sometimes date back to the Soviet era, the most recent ones usually appeared in the first decade of the twenty-first century. The problem lies, however, in the inadequate reliability of the regional editions, as we elaborate below.

The entomofauna of many regions of Russia is poorly studied, so it is hardly ever possible to follow strictly the objective criteria of the IUCN due to the lack of data on species abundance and occurrence. While normally species population trends can be inferred from the changes in habitat availability, as long as basic knowledge of the species ecology and distribution is available, this is again rarely realistic in such a vast and diverse country as Russia, where comprehensive information on the state of habitats is lacking as well. All concerned, the species status evaluation is frequently done using the purely subjective 'expert assessment' approach (Poltavsky 2011). Consequently, more appealing insects species (those of large size, unusual shape, or interesting colours) are more likely to be listed even if they are not really at risk (Shilenkov 2010). The best example here are probably tiger moths (Arctiidae), highly represented in almost all Red Data Books of the Siberia region, in spite of the fact that they mostly live in the highlands or other remote places under no particular treat. Similarly, even within less charismatic groups such as ground beetles, large species dominate the lists and small ones are hardly ever considered (Shilenkov 2010).

Furthermore, the selection of species listed in the regional Red Data Books often depends on the interests, expertise, and the number of people and institutions involved in drafting the books, which is evident in the high variation in the numbers of the listed insect species among the books. Obviously, these numbers are affected by the richness of regional insect fauna so much variation in them should be expected, however striking differences exist even between the neighbouring regions with comparable size and fairly similar entomofauna. For instance, the Red Data Book of Karelia includes 255 insect species, while that of the adjacent Arkhangelsk oblast contains less than 50 species. Further pair-wise comparison of neighbouring regions reveal analogous discrepancies, e.g. between the Zabaykalsky Krai and the Amur oblast ( 75 vs. 26 species), the Novosibirsk oblast and the Altai Krai (58 vs. 30 species) or the Chuvash Republic and the Mari El Republic (145 vs. 84 species). The above two- to five-fold differences in the listed species numbers apparently indicate the lack of concordance in the principles of species selection procedures, thus undermining any joint analyses of their outcomes.

\section{Sozological analysis as alternative way of species prioritisation}

While both the Russian and regional editions of Red Data Books have been repeatedly criticized for their subjectivity in their species listing, especially concerning insect fauna (Bol'shakov 2008), it has been postulated that the IUCN criteria should be precisely followed as they are well-designed, clearly structured, standardised, objective, and theoretically sound (Korb 2015). However, as previously explained, strict adherence to the IUCN criteria does not appear feasible in the Russian reality due to the lack of detailed quantitative data on the state and trends of most insect species. In such a situation a useful alternative seems to be offered by sozological analysis, which most recently has been increasingly used in regional Red Data Books (Lagunov 2011, 2015; Haritonov et al. 2014; Popov and Shapovalov 2014). The term "sozology" was first introduced by Goetel (1966) and it refers to the study of nature protection (from Greek "sozo" $=$ to protect). The sozological analysis combines numerous criteria which reflect both the ecological status of focal species as well as their values for human society. Each criterion is evaluated through a simple rank-based scoring system and assigned a specific weight.

The most versatile tool applied in sozological analysis is the Saksonov-Rozenberg matrix (Saksonov and Rozenberg 2000), later adapted for insects by Lagunov (2011), who modified the weights given to particular sozological characteristics used as criteria. The matrix comprises twelve criteria with the weights ranging from 1 to 5 (Table 2). A species is scored 1 to 4 points for each of the criteria. These scores are multiplied by the criteria weights and the integrated sozological assessment of the species is subsequently derived as the sum of the points obtained (Table S1 in the Electronic Supplementary Material). Based on this summarised score the species can be classified as Critically Endangered (120-136 points), Endangered (102-119 points), Very Rare (85-101 points), Moderately Rare (68-84 points) or Non-endangered ( $<68$ points) (Lagunov 2013). Both categories of rare species are assumed to correspond roughly to the IUCN category of Vulnerable species. The comparison of the species lists of the regional Red Data Books and the 
Table 2 Saksonov-Rozenberg matrix as applied in sozological analysis for selecting insect species of conservation importance (Lagunov 2011)

\begin{tabular}{|c|c|c|c|c|c|c|}
\hline \multirow[t]{2}{*}{ Criterion no. } & \multirow{2}{*}{$\begin{array}{l}\text { Sozological character- } \\
\text { istics of species }\end{array}$} & \multirow[t]{2}{*}{ Weight } & \multicolumn{4}{|l|}{ Score } \\
\hline & & & 1 & 2 & 3 & 4 \\
\hline 1 & $\begin{array}{l}\text { Relative abundance (in } \\
\text { typical habitats) }\end{array}$ & 5 & Dominant & Common & Rare & Very rare \\
\hline 2 & $\begin{array}{l}\text { Number of inhabited } \\
\text { sites in the region }\end{array}$ & 5 & $>30$ & $11-30$ & $6-10$ & $1-5$ \\
\hline 3 & $\begin{array}{l}\text { Trend of change in } \\
\text { abundance }\end{array}$ & 4 & Increasing & Stable & Slightly decreasing & Sharply decreasing \\
\hline 4 & $\begin{array}{l}\text { Vulnerability to } \\
\text { anthropogenic } \\
\text { threats }\end{array}$ & 4 & Weak & Moderate & High & Very high \\
\hline 5 & $\begin{array}{l}\text { Ecological niche } \\
\text { breadth }\end{array}$ & 3 & Broad & Moderate & Narrow & Very narrow \\
\hline 6 & $\begin{array}{l}\text { Biogeographic signifi- } \\
\text { cance }\end{array}$ & 3 & $\begin{array}{l}\text { Species within core } \\
\text { area of its continuous } \\
\text { distribution }\end{array}$ & $\begin{array}{l}\text { Species within core } \\
\text { area of its discon- } \\
\text { nected (= patchy) } \\
\text { distribution }\end{array}$ & $\begin{array}{l}\text { Species at the edge of } \\
\text { its distribution }\end{array}$ & $\begin{array}{l}\text { Species in enclave } \\
\text { out of its stand- } \\
\text { ard distribution }\end{array}$ \\
\hline 7 & Distribution range & 3 & $\begin{array}{l}\text { Intercontinental spe- } \\
\text { cies }\end{array}$ & Continental endemic & Regional endemic & Local endemic \\
\hline 8 & $\begin{array}{l}\text { Territorial protection } \\
\text { (presence within } \\
\text { protected areas) }\end{array}$ & 2 & $\begin{array}{l}\text { Protected areas with } \\
\text { various protection } \\
\text { regimes }\end{array}$ & $\begin{array}{l}\text { Only faunistic pro- } \\
\text { tected areas }\end{array}$ & $\begin{array}{l}\text { Only non-specialised } \\
\text { protected areas }\end{array}$ & None \\
\hline 9 & $\begin{array}{l}\text { Official conservation } \\
\text { status }\end{array}$ & 2 & $\begin{array}{l}\text { Listed in the IUCN } \\
\text { Red Data Book }\end{array}$ & $\begin{array}{l}\text { Listed in the Red Data } \\
\text { Book of the Russian } \\
\text { Federation }\end{array}$ & $\begin{array}{l}\text { Listed in other } \\
\text { regional Red Data } \\
\text { Books }\end{array}$ & None \\
\hline 10 & Scientific value & 1 & Insignificant & Moderate & High & Very high \\
\hline 11 & Aesthetic value & 1 & Insignificant & Moderate & High & Very high \\
\hline 12 & Economic value & 1 & Insignificant & Moderate & High & Very high \\
\hline
\end{tabular}

Table 3 The comparison of the numbers of insect species included in the regional Red Data Books and the outcomes of sozological analyses for the selected regions of Russia

\begin{tabular}{lllll}
\hline Region (species group) & & Udmurt Republic (butterflies) & $\begin{array}{l}\text { Chelyabinsk } \\
\text { Oblast (all } \\
\text { insects) }\end{array}$ & Republic of Adygea (all insects) \\
\hline Red Data Book categories & Critically Endangered & - & 8 & - \\
& Endangered & - & 11 & 23 \\
& Vulnerable & 13 & 27 & 52 \\
& Near threatened & 1 & 49 & - \\
& Least concern & - & - & 122 \\
& Total & 14 & 95 & Zamotajlov (2012) \\
Source & & Baranova (2012) & - & $84^{*}$ \\
Sozological analysis categories & Critically Endangered & 7 & 5 & 48 \\
& Endangered & 12 & 39 & - \\
& Very Rare & 12 & 63 & - \\
& Moderately rare & 27 & 132 & Zamotajlov et al. (2015) \\
\hline
\end{tabular}

Critically Endangered and Endangered species were not distinguished in the sozological analysis for the Republic of Adygea and thus the number marked with asterisk refers to both categories pooled together 
outcomes of sozological analyses conducted for the same regions indicates that the latter are generally more inclusive (Table 3), which is understandable since the species on which there is only limited ecological knowledge can also be considered. Furthermore, sozological analyses typically assign more species to higher categories of conservation concern, which in the case of Red Data Books are more difficult to be granted if the information on the magnitude of species decline is lacking.

The approach adopted in sozological analyses seems a highly promising solution, combining applicability for datadeficient species (which is typically the case of insects in Russia) with objectivity and reliability of the assessment. Although developed independently and virtually unknown outside Russia and the neighbouring states formerly making Soviet Union, this simplified method of prioritising species of conservation concern is not entirely unique. Several alternatives to the standard Red List categorisation following IUCN criteria were suggested and successfully applied in the past; combining various indices of species rarity, vulnerability or taxonomic distinctiveness (e.g. Kattan 1992; Freitag and van Jaarsveld 1997; Fattorini 2010, 2011, 2014; Matenaar et al. 2015; Miličić et al. 2017). The Russian sozological analyses are generally based on similar principles (except for disregarding taxonomic distinctiveness), with the rare and more vulnerable species receiving higher scores and thus being assigned to higher categories of conservation concern. However, their peculiarity is the fact that some consideration is also given to scientific, aesthetic and economic values of evaluated insect species.

\section{Conclusions}

With its extensive territory and high diversity of natural habitats, Russia faces tremendous challenges in the efforts to conserve its entomofauna. The most obvious problem is the lack of basic information on the state and trends of the population of all insect species except for the few well-studied ones. While it can be argued that the lack of country-wide monitoring schemes is to blame for this, such a situation is in fact a reality in most other countries as well. Even in the Western world with its long tradition of strong public involvement in biodiversity monitoring, insect monitoring programmes are restricted to several popular groups (butterflies, dragonflies, selected beetles) in just a few countries (van Swaay et al. 2008; McGeoch et al. 2011; Sebek et al. 2012). This may be enough for the purpose of using insects as indicators of large-scale biodiversity trends (Feest 2013), but it does not help in the objective selection of species of conservation concern in all other insect groups.

Due to the lack of relevant data, the Russian system of drawing the lists of insects included in the national and regional Red Data Books, and thus legally protected, has long been based on subjective expert assessments. The system has been widely criticised for both listing some charismatic species under no particular threat as well as for omitting others which deserved to be conserved but simply do not attract adequate expert attention. The recently proposed use of sozological analysis for prioritising species appears a promising solution in this respect. The clearcut quantitative criteria of the IUCN may be very well-grounded in the scientific theory, but they are often difficult to be applied in practice because of data shortage (Mace et al. 2008). In turn, sozological analysis relying on qualitative ranking system can be applied for data-deficient species, but it still remains an unbiased rule-based procedure. Moreover, it is relatively flexible and can be easily adjusted, e.g. through removing certain criteria, adding new ones, or modifying their weights, if the conservation priorities change. This may be helpful in the ongoing process of regionalisation of the lists of conservation concern species, which is indeed highly recommendable for an extensive and diverse country like Russia.

Unfortunately, declaring the status of legally protected species is often the end, and not the beginning of conservation efforts in the Russian reality. There is a strong focus on the passive protection of the species themselves, and not on the active preservation of their habitats. Such an approach may occasionally work in the conservation of some large vertebrates, for which direct extermination by humans is the main driver of decline, but it is not effective for insects, usually associated with particular habitat types, many of which require continuous management to persist (Fenner and Palmer 1998; Bubova et al. 2015). A noteworthy exception in the predominantly passive insect conservation in Russia are the entomological microreserves dedicated to some insect groups. Promoting this form of nature protection areas is not only highly recommendable for Russia, but it also seems a potentially useful solution for many other countries.

Acknowledgements The study was supported by the Ministry of Education and Science of the Russian Federation (Grant REMEFI61316X0060) and the Polish National Science Centre (Grant DEC-2013/11/B/NZ8/00912). We are grateful to C. Richards and A. Houska for improving the English of the manuscript. A.S. Zamotajlov and D.A. Adakhovskiy provided useful advice for the manuscript, while S.M. Krasnopeev helped in the preparation of the maps.

\section{Compliance with ethical standards}

Conflict of interest The authors declare that they have no conflict of interest.

Ethical approval The authors declare that they have complied with ethical standards. 
OpenAccess This article is distributed under the terms of the Creative Commons Attribution 4.0 International License (http://creativeco mmons.org/licenses/by/4.0/), which permits unrestricted use, distribution, and reproduction in any medium, provided you give appropriate credit to the original author(s) and the source, provide a link to the Creative Commons license, and indicate if changes were made.

\section{References}

Adakhovskiy DA (2017) Threatened analysis of diurnal butterflies (Lepidoptera: Hesperioidea, Papilionoidea) in the Udmurt Republic. Vestnik Udmurt Univ Seriya Biol Earth Sci 27:180190 [in Russian]

Baranova OG (ed) (2012) Red Data Book of the Udmurt Republic. Perfectum, Cheboksary [in Russian]

Barkalov A (2007) Altai-the source of new species of insects. Priroda 12:24 [in Russian]

Baz A, Garcia-Boyero A (1996) The SLOSS dilemma: a butterfly case study. Biodivers Conserv 5:493-502

Beketov MA, Kefford BJ, Schäfer RB, Liess M (2013) Pesticides reduce regional biodiversity of stream invertebrates. Proc Natl Acad Sci 110:11039-11043

Belokobylsky SA, Lelej AS (eds) (2017) Annotated catalogue of Hymenoptera insects of Russia. vol I. Symphyta and Apocrita: Aculeata. Zoological Institute of RAS, St. Petersburg [in Russian]

Belova YuN (2014) Fauna and population of ground beetles (Coleoptera, Carabidae) in forest ecosystems on the territory of the Vologda oblast. Vologda state University, Vologda [in Russian]

Bol'shakov LV (2008) Review of the book V.I. Shchurov, A.S. Zamotailov. Experience in the development of the regional list of protected species of insects on the example of Krasnodar Krai and Republic of Adygea. Eversmannia Entomol Stud Russ Neighb Reg 13-14:87-102 [in Russian]

Borodin AM, Bannikov AG, Sokolov VE (eds) (1984) Red Data Book of the USSR. Forest Industry, Moscow [in Russian]

Bubova T, Vrabec V, Kulma M, Nowicki P (2015) Land management impacts on European butterflies of conservation concern: a review. J Insect Conserv 19:805-821

Byvaltsev AM (2009a) The communities of bumble bees (Hymenoptera: Apidae, Bombini) in the city of Novosibirsk and its environs. Contemp Probl Ecol 2(3):216-223 [in Russian]

Byvaltsev AM (2009b) Bumblebees (Hymenoptera: Apidae, Bombini) in forest-steppe and steppe South of Western Siberian plain: fauna and population. Dissertation. Institute of Systematics and Ecology of Animals SB RAS, Novosibirsk [in Russian]

Cardoso P, Borges PAV, Triantis KA, Ferrández MA, Martín JL (2011) Adapting the IUCN Red List criteria for invertebrates. Biol Conserv 144:2432-2440

Chape S, Spalding M, Jenkins MD (2008) The World's protected areas: status, values and prospects in the 21 st century. University of California Press, Berkeley

Chenikalova EV, Eremenko RS, Mokhrin AA (2008) Protection of rare and useful insects: study guide. AGRUS, Stavropol [in Russian]

Chernov NN (2002) Silvicultural business in the Urals: Formation, status, ways of further development. USFEU, Yekaterinburg [in Russian]

Collins NM, Morris MG (1985) Threatened swallowtail butterflies of the world: the IUCN Red Data Book. IUCN, Gland

Collins NM, Thomas JA (eds) (1991) The conservation of insects and their habitats. Academic Press, London

Conforti S, Dietrich J, Kuhn T, van Koppenhagen N, Baur J, Rohner PT, Blanckenhorn WU, Schafer MA (2018) Comparative effects of the parasiticide ivermectin on survival and reproduction of adult sepsid flies. Ecotox Environ Safe 163:215-222

Danilevsky ML (2014) Longhorn beetles (Coleoptera, Cerambycidae) of Russia and neighboring countries, vol 1. Higher School of Social Management and Consulting, Moscow [in Russian]

Danilova SN, Petrov AM, Taislyna OG, Trofimenko AV (2018) Public management of protected natural areas in Russia. Bull Saratov State Soc Econ Univ 2(71):79-86 [in Russian]

Danilov-Danilyan VI (ed) (2001) Red Data Book of the Russian Federation (animals). AST Astrel, Moscow [in Russian]

Eliseev VN (ed) (1983) Red book of the RSFSR. Animals. Rosselkhozizdat, Moscow [in Russian]

Engel MS, Hinojosa-Diaz I, Rasnitsyn IA AP (2009) A honey bee from the Miocene of Nevada and the biogeography of Apis (Hymenoptera: Apidae: Apini). Proc Calif Acad Sci 60:23-38

Ermolenko VM (1973) On the protection of useful, endemic and relict insects of the Ukrainian Carpathians and Mountain Crimea. In: On the protection of insects. Yerevan, pp 29-35 [in Russian]

European Commission (1992) Council Directive 92/43/EEC of 21 May 1992 on the Conservation of natural habitats and of wild fauna and flora. Off J Eur Union Legis 206:7

European Environment Agency (2018) Natura 2000 Network Viewer. http://natura2000.eea.europa.eu/. Accessed 2 Nov 2018

Evans D (2012) Building the European Union's Natura 2000 network. Nature Conserv 1:11-26

Fattorini S (2010) Use of insect rarity for biotope prioritisation: the tenebrionid beetles of the Central Apennines (Italy). J Insect Conserv 14:367-378

Fattorini S (2011) Insect rarity, extinction and conservation in urban Rome (Italy): a 120-year-long study of tenebrionid beetles. Insect Conserv Divers 4:307-315

Fattorini S (2014) Relations between species rarity, vulnerability, and range contraction for a beetle group in a densely populated region within the Mediterranean biodiversity hotspot. Conserv Biol 28:169-176

Feest A (2013) The utility of the streamlining European biodiversity indicators 2010 (SEBI 2010). Ecol Indic 28:16-21

Fenner M, Palmer L (1998) Grassland management to promote biodiversity: Creation of a patchy sward by mowing and fertiliser regimes. Field Stud 9:313-324

Fletcher RJJ, Ries L, Battin J, Chalfou AD (2007) The role of habitat area and edge in fragmented landscapes: definitively distinct or inevitably intertwined? Can J Zool 85:1017-1730

Freitag S, van Jaarsveld AS (1997) Relative occupancy, endemism, taxonomic distinctiveness and vulnerability: prioritizing regional conservation actions. Biodivers Conserv 6:211-232

Gaston KJ, Jackson SF, Nagy A, Cantu-Salazar L, Johnson M (2008) Protected areas in Europe: principle and practice. Ann NY Acad Sci 1134:97-119

Gilpin ME, Diamond JM (1980) Subdivision of nature reserves and the maintenance of species diversity. Nature 285:567-568

Goetel W (1966) Sozology - the science of protecting nature and its resources. Kosmos 5:473-482 [in Polish]

Gorbunov OG, Murzin VS (2009) Butterflies. http://gordon0030.narod .ru/archive/19977. Accessed 4 Dec 2017 [in Russian]

Gordeev SY (2016) New records of nemoral Nymphalidae butterfly species (Lepidoptera, Diurna) in southwestern part of the Zabaikalskii Krai of Russia. Eurasian Entomol J 15:563-565 [in Russian]

Grebennikov VS (1972) To the protection of bumble bees as a valuable pollinators. In: Nature conservation and rational use of natural resources in the Central Chernozem band. Voronezh state University, Voronezh, pp 78-82 [in Russian]

Grebennikov VS (1990) Secrets of the insect world. Novosibirsk Publishing house, Novosibirsk [in Russian] 
Griffin PC (1999) Endangered species diversity 'hot spots' in Russia and centers of endemism. Biodivers Conserv 8:497-511

Haritonov AY, Eremina EE (2010) The dragonflies (Odonata) of South Ural: the value of regional faunistic research. Eurasian Entomol J 9:263-273 [in Russian]

Haritonov AY, Popova ON, Lagunov AV (2014) Sozological analysis of dragonflies (Odonata) of the Southern Urals. Euroasian Entomol J 13:301-314 [in Russian]

Henning GA, Terblanche RF, Ball JB (2009) South African Red Data book: butterflies, SANBI Biodiversity Series 13. South African National Biodiversity Institute, Pretoria

Kabakov ON (2006) Leaf-horned beetles of the subfamily Scarabaeinae of the fauna of Russia and adjacent countries. Association of Scientific Publications KMK, Moscow [in Russian]

Kajzer-Bonk J, Nowicki P, Bonk M, Skórka P, Witek M, Woyciechowski M (2013) Local populations of endangered Maculinea (Phengaris) butterflies are flood resistant. J Insect Conserv 17:1105-1112

Kassal DB, Kassal BY, Kraynov IV (2016) Entomological reserve in the Omsk region as an object of educational process. Juvenis Sci 2:46-48 [in Russian]

Kattan G (1992) Rarity and vulnerability: the birds of the Cordillera Central of Colombia. Conserv Biol 6:64-70

Kery M, Schmid H (2004) Monitoring programs need to take into account imperfect species detectability. Basic Appl Ecol 5:65-73

Klepikov M (2002) Skippers (Hesperiidae). Biology 6:14-17 [in Russian]

Klyuchnikov LY (2005) Forest crafts of Ancient Russia. For Bull 2:184-186 [in Russian]

Kochetova NI, Akimushkin MI, Dykhnov VN (1986) Rare invertebrates. Agropromizdat, Moscow [in Russian]

Korb SK (2015) Evaluation of butterflies (Lepidoptera, Rhopalocera) of Kyrgyz republic using IUCN criteria and recommendations for inclusion Rhopalocera species in the Red book Interdisciplinary Scientific and. Appl J Biosph 7(4):421-428 [in Russian]

Korytin NS (ed) (2005) Red Data Book of Chelyabinsk oblast: animals, plants, fungi. Publishing house of Ural University, Ekaterinburg [in Russian]

Koshkin ES, Rogatnykh DY, Bezborodov VG (2016) Ground beetles (Coleoptera: Carabidae) of the Bureinskii State Nature Reserve, Khabarovskii Krai, Russia. Eurasian Entomol J 15:309-318 [in Russian]

Kovalenko VI (2009) Features of blooming dynamics in alfalfa plants during different pollination regimes. Agric Biol 3:93-97 [in Russian]

Kozhevnikov GA (1926) School teacher and the nature conservancy. Moscow [in Russian]

Kurentsov AI (1964) On the protection of some useful and relict insect species of the Ussuri fauna. In: Nature protection in the Russian Far East, Vladivostok, pp 103-111 [in Russian]

Lagunov AV (2004) Role of specially protected natural areas of the Chelyabinsk oblast in the protection of rare species of insects. In: Proceedings of the Chelyabinsk Scientific Center of UB RAS 3, pp. 116-121 [in Russian]

Lagunov AV (2011) Sozological analysis of blister beetles (Meloidae, Coleoptera) of Chelyabinsk region. Vestnik Orenburg State Univ 12(131):101-103 [in Russian]

Lagunov AV (2013) Sozological analysis of protected invertebrates in Chelyabinsk oblast. Bulletin of the Orenburg State Pedagogical University. Electron Sci J 3(7):26-35 [in Russian]

Lagunov AV (2015) Insects from the Red Data Book of Kurgan oblast: sozological analysis. Bull Kurgan State Univ Ser Nat Sci 1(35):7-13 [in Russian]

Lelej AS, Storozhenko SY (2010) Insect taxonomic diversity in the Russian Far East. Entomol Rev 90:372-386 [in Russian]
León-Cortés JL, Lennon JJ, Thomas CD (2003) Ecological dynamics of extinct species in empty habitat networks. 1. The role of habitat pattern and quantity, stochasticity and dispersal. Oikos 102:449-464

Lockwood JA, Sergeev MG (2000) Comparative biogeography of grasshoppers (Orthoptera: Acrididae) in North America and Siberia: applications to the conservation of biodiversity. J Insect Conserv 4:161-172

Logvinovsky VD (1996) Establishment of a network of entomological microreserves and nature-sanctuaries as one of ways of optimization of agrolandscapes. In: Proceedings of the international scientific conference biological problems of sustainable development of natural ecosystems, 11-13 September 1996, Voronezh, pp. 69-71 [in Russian]

Mace GM, Collar NJ, Gaston KJ, Hilton-Taylor C, Akcakaya HR, Leader-Williams N, Milner-Gulland EJ, Stuart SN (2008) Quantification of extinction risk: IUCN's system for classifying threatened species. Conserv Biol 22:1424-1442

MacKenzie DI, Nichols JD, Lachman GB, Droege S, Royle JA, Langtimm CA (2002) Estimating site occupancy rates when detection probabilities are less than one. Ecology 83:2248-2255

Matenaar D, Bazelet CS, Hochkirch A (2015) Simple tools for the evaluation of protected areas for the conservation of grasshoppers. Biol Conserv 192:192-199

Mazin LN (1999) Insects in the Red Data Book of the Russian Federation. Entomologicheskoe Obozrenie 78(2):483-488 [in Russian]

McGeoch MA et al (2011) Conservation and monitoring of invertebrates in terrestrial protected areas. Koedoe 53: Art \#1000. https ://doi.org/10.4102/koedoe.v53i2.1000

Medvedsky VA, Medvedskaya TV (2010) Agricultural ecology. ICC Ministry of Finance, Minsk [in Russian]

Miličić M, Vujić A, Jurca T, Cardoso P (2017) Designating conservation priorities for Southeast European hoverflies (Diptera: Syrphidae) based on species distribution models and species vulnerability. Insect Conserv Divers 10:354-366

Moskalenko IV (2016) Optimization of functioning of especially protected natural territories in conservation of biodiversity and development of ecological tourism (on the example of Bryansk oblast). Dissertation, Bryansk State University [in Russian]

Munguira ML (1995) Conservation of butterfly habitats and diversity in European Mediterranean countries. In: Pullin AS (ed) Ecology and the conservation of butterflies. Chapman and Hall, London, pp 277-289

Nakonieczny M, Kędziorski A, Michalczyk K (2007) Apollo butterfly (Parnassius apollo L.) in Europe - its history, decline and perspectives of conservation. Funct Ecosyst 1:56-79

New TR, Pyle RM, Thomas JA, Thomas CD, Hammond PC (1995) Butterfly conservation management. Annu Rev Entomol 40:57-83

Nieto A, Alexander KNA (2010) European Red List of saproxylic beetles. Publications Office of the European Union, Luxembourg

Nikitsky NB, Sviridov AV (1987) Insects of the Red Data Book of the USSR. Pedagogika, Moscow [in Russian]

Nowicki P, Bonelli S, Barbero F, Balletto E (2009) Relative importance of density-dependent regulation and environmental stochasticity for butterfly population dynamics. Oecologia 161:227-239

Nowicki P, Halecki W, Kalarus K (2013) All natural habitat edges matter equally for endangered Maculinea butterflies. J Insect Conserv 17:139-146

Nowicki P, Marczyk J, Kajzer-Bonk J (2015) Metapopulations of endangered Maculinea butterflies are resilient to large-scale fire. Ecohydrology 8:398-405

Pereletov RN (2008) Products of bee-keeping in the markets of the Don River basin and the East Europe in 8th-15th centuries. 
Herald Voronezh State Univ Ser Hist Polit Sci Sociol 2:84-90 [in Russian]

Platonova MA, Belova YuN (2011) The protection of insects in the Vologda oblast. Successes Mod Nat Sci 7:29 [in Russian]

Poltavsky AN (2011) Principles of the insect list making for the Red Book of the Rostov-on-Don area. Ecol Bull N Cauc 7(2):51-57 [in Russian]

Poltavsky AN, Poltavskaya MP (2010) Role of regional red lists in the conservation of biological diversity of insects. Scientific Proceedings of the State Nature Reserve "Prisursky" 24:118-120 [in Russian]

Popov IB, Shapovalov MI (2014) Sozological characteristic of hymenopterous insects (Insecta, Hymenoptera) of special economic zone of the Maikop region, Adyghea Republic. Bull Adygea State Univ Ser 4 Nat Math Tech Sci 3(142):62-71 [in Russian]

Primack RB (2002) Essentials of conservation biology, 3rd edn. Sinauer Associates, Sunderland

Saksonov SV, Rozenberg GS (2000) Organizational and methodological aspects of regional Red books. Institute of Ecology of Volga Basin, Tol'yatti [in Russian]

Sebek P et al (2012) A test for assessment of saproxylic beetle biodiversity using subsets of "monitoring species". Ecol Indic 20:304-315

Shafer CL (2001) Inter-reserve distance. Biol Conserv 100:215-227

Shchurov VI, Zamotajlov AS (2006) Experience in the development of the regional list of protected species of insects on the example of Krasnodar Krai and Republic of Adygea. Readings in Memory of N. Kholodkovsky 59:1-216 [in Russian]

Sinev SY (ed) (2008) The catalogue of butterflies (Lepidoptera) of Russia. Association of Scientific Publications KMK, Moscow [in Russian]

Soule ME, Simberloff D (1986) What do genetics and ecology tell us about the design of nature reserves? Biol Conserv 35:19-40

Speranskaya KS, Zaitsev AS (2011) Protection of rare insects in the reserves of European Russia. In: Geographical foundations of ecological nets creation in Russia and Eastern Europe. Part 1. Partnership of Scientific Publications KMK, Moscow, pp 259263 [in Russian]

Stepanitskiy VB (2016) Development of system of protected areas in the regions of Russia and biodiversity conservation. http:// news.zapoved.ru/2016/03/09/razvitie-sistem-oopt-v-regionahrossii-i-sohranenie-bioraznoobraziya/. Accessed 27 Oct 2018 [in Russian]

Stepanitskiy VB, Sinitsyn MG (2008) Methodical recommendations on the organization of specially protected natural areas of regional importance-handbook. UNDP/GEF project "Biodiversity Conservation in the Russian part of Altai-'Sayan Ecoregion”, Krasnoyarsk [in Russian]

Streltsov AN, Gluschenko YuN (2005) Family Papilionidae-Swallowtails. In: Belyaev EA, Viidalepp IP, Glushchenko YuN, Dubatolov VV, Efetov KA., Kirpichnikova VA, Kononenko VS, Kosterin OE, Kuznetsov VI, Lukhtanov VA, Mironov VG, Sergeev MG, Streltsov AN, Chistyakov YuA (eds) The determinants of insects of the Russian Far East. Dalnauka, Vladivostok, pp 188-207 [in Russian]
Shilenkov VG (2010) Rare carabids (Coleoptera, Carabidae) of Baikal region and the principles of preservation of insects. Izvestiya of Irkutsk State University. Ser Biol Ecol 3:37-41 [in Russian]

Strong L, Wall R (1994) Effects of ivermectin and moxidectin on the insects of cattle dung. B Entomol Res 84:403-409

Sundukov YuN, Lelej AS (2009) Sawflies (Hymenoptera, Symphyta) of the Russian far east. Additions and corrections. Far Eastern Entomol 200:1-12

Sviridov AV (2011) Principles of insects protection (after the example of Lepidoptera): history and perspectives. Bulleten' Moskovskogo Obschestva Ispytateley Prirody. Otdel Biologichesky 116(6):3-19 [in Russian]

Thomas CD, Hanski I (1997) Butterfly metapopulations. In: Hanski I, Gilpin ME (eds) Metapopulation biology. Ecology, genetics, and evolution. Academic Press, San Diego, pp 359-386

Thomas JA, Simcox DJ, Hovestadt T (2011) Evidence based conservation of butterflies. J Insect Conserv 15:241-258

Tikhonov AV (2002) Red Data Book of Russia. The animals and plants. ROSMEN, Moscow [in Russian]

Tilman D, Cassman KG, Matson PA, Naylor R, Polasky S (2002) Agricultural sustainability and intensive production practices. Nature 418:671-677

Tuzov VK, Bodganov PV, Devyatkin AL, Kaabak LV, Korolev VA, Murzin VS, Samodurov GD, Tarasov EA (1997) Guide to the butterflies of Russia and adjacent territories, vol 1. Pensoft Publishers, Sofia

Tye H (1991) World Conservation Union East European Programme. The lowland grasslands of Central and Eastern Europe. IUCN, International Press, Oxford

van Swaay CAM, Nowicki P, Settele J, van Strien AJ (2008) Butterfly monitoring in Europe: methods, applications and perspectives. Biodivers Conserv 17:3455-3469

van Swaay C et al (2010) European red list of butterflies. Publications Office of the European Union, Luxembourg

Zakharov AA (2003) Myrmecology is forest science. For Bull 2:69-74 [in Russian]

Zamotajlov AS (ed) (2012) Red Data Book of Republic of Adygea. Rare and threatened representatives of the regional fauna and flora. Part 2. Animals. Kachestvo, Maykop [in Russian]

Zamotajlov A, Shapovalov M, Saprykin M, Varshanina T (2015) Development of objective sozological zoning in the territory of the Republic of Adygea (as exemplified by invertebrates). Indian J Sci Technol 8:1-6

Zinchenko VK, Ivanov AV (2006) A review of stag beetles (Coleoptera, Lucanidae) of West Siberia. Eurasian Entomol J 5:235-238 [in Russian]

ZooClub (2017) Mega encyclopaedia of animals. http://www.zoocl ub.ru/chlen/nasek/79.shtml. Accessed 23 Aug 2017 [in Russian]

Publisher's Note Springer Nature remains neutral with regard to jurisdictional claims in published maps and institutional affiliations. 